\title{
Anaerobically Digested Dairy Fiber in Soilless Potting Media for Herbaceous Perennials
}

\author{
John R. Lamont, George C. Elliott \\ Department of Plant Science and Landscape Architecture, University of Connecticut, Storrs, CT, USA \\ Email: john.lamont@mail.mcgill.ca
}

Received 19 January 2016; accepted 19 February 2016; published 22 February 2016

Copyright @ 2016 by authors and Scientific Research Publishing Inc.

This work is licensed under the Creative Commons Attribution International License (CC BY).

http://creativecommons.org/licenses/by/4.0/

(c) (i) Open Access

\section{Abstract}

Sphagnum peat moss has been a primary component of soilless potting media for decades; however, concerns over the sustainability of harvesting peat have fostered a search for renewable media components. Anaerobically digested dairy fiber (ADDF), a by-product of methane production, shows promise as an alternative to peat. Herbaceous nursery crops including "Jack Frost" brunnera (Brunnera macrophylla I.M. Johnst), "Moonbeam" coreopsis (Coreopsis verticillata L.), "Whoopsa-Daisy" Shasta daisy (Leucanthemum $\times$ superbum Bergmans ex J.W. Ingram), "Kobold Original" liatris (Liatris spicata (L.) Willd.) and "David" phlox (Phlox paniculata L.) were grown in media containing bark-peat-perlite or bark-ADDF-perlite in a 4:2:1 proportion. All leachate was collected from pots to evaluate cumulative nitrogen and phosphate leaching. Brunnera grew to a similar size and quality in both mixes, although brunnera in the bark-ADDF-perlite mix had slightly chlorotic leaf margins. Coreopsis grew to a similar size and quality in both mixes but was slightly etiolated and chlorotic in bark-ADDF-perlite. Shasta daisy grown in bark-ADDF-perlite were larger than those grown in bark-peat-perlite. Both mixes produced similar growth and quality liatris and phlox. More ammonium, nitrate and phosphate were recovered from leachate from bark-ADDFperlite than from bark-ADDF-perlite.

\section{Keywords}

Peat Substitution, Substrate, Nursery Crops, Ornamentals, Nutrient Leaching

\section{Introduction}

Peat has been one of the principal components of potting media for decades due to physiochemical properties 
that are excellent for plant growth and adaptable to a wide range of management practices [1]. Despite the usefulness of peat, there are important environmental concerns related to its harvest. Peatlands are fragile ecosystems that can be severely, and perhaps permanently, damaged by peat harvesting [2]. Additionally, harvesting peat releases carbon sequestered in peatlands, contributing to climate change [3].

Research to find suitable and renewable alternatives to peat has been ongoing for decades. Alternatives to peat must have physiochemical properties that are both suitable to plant growth and compatible with growing practices [4]. Many potential alternatives are by-products of the agricultural and food industries; these are especially appealing because they are renewable resources and change a problem of waste management to an opportunity to generate revenue from a high-value horticultural product [4]. While there have been successes growing plants in such peat replacements, their use is commonly limited by unpredictable variability in their physical and chemical properties, resulting in non-uniform crops [5]. Chong [6] has been successfully using a variety of waste and compost products to grow nursery crops for over 20 years; however, these products tend to become compacted and lose porosity over time when used in media for long-term crops. Shober et al. [7] successfully used aerobically composted dairy manure as a replacement for peat in a nursery mix but found that it produced large quantities of phosphate runoff.

Anaerobically digested dairy fiber (ADDF), a by-product of methane production from dairy manure, has physical properties similar to peat [8]. While anaerobic digestion is an environmentally sound way to process dairy manure, it is often prohibitively expensive for small dairies [9]. Currently, ADDF is mostly used on site as a field soil amendment or as animal bedding. Finding a more lucrative outlet for ADDF, like as a potting media component, could provide smaller dairies more incentive to adopt anaerobic digestion for waste disposal [10]. Creating a local market for ADDF as a potting media component could also benefit growers by providing an inexpensive alternative to peat [11], which is often imported long distances from cold, northern climates to horticultural areas [12]. Growers could also market their crops as "sustainable”, a label that can command a higher price for ornamental crops [13].

Other anaerobically digested organic material, such as potatio waste [14] and sewage sludge [15] have been successfully used as partial peat replacements in potting media. ADDF has been evaluated as a replacement for peat in media for bedding plants [16] and a variety of other container-grown plants including poinsettia, chrysanthemum and cyclamen [8] with generally favorable results. Currently there is no information published about growing herbaceous perennials in ADDF mixes. Previous trials with ADDF as a media component have shown that ADDF contains a significant amount of soluble nitrogen and phosphorus [8], which contributes to plant nutrition but may also present a nutrient leaching problem.

The objectives of this research were to evaluate ADDF as a substitute for peat in nursery mixes and to evaluate nutrient leaching from nursery mixes containing ADDF.

\section{Materials and Methods}

Two potting mixes were formulated containing bark-peat-perlite and bark-ADDF-perlite each in a 4:2:1 ratio. The bark-ADDF-perlite mix was amended with $4 \mathrm{~g} \cdot \mathrm{L}^{-1}$ gypsum and the bark-peat-perlite mix was amended with $2.5 \mathrm{~g} \cdot \mathrm{L}^{-1}$ dolomitic lime. Three samples were collected from each mix and Saturated Media Extracts (SME) [17] were obtained. Electrical conductivity (EC) and pH of SME were measured using Cardy Twin pH and conductivity meters (Horiba Corp., Kyoto, Japan).

All starter plant material was obtained from Walters Gardens Inc. (Zeeland, MI). Plugs of brunnera (Brunnera macrophylla “Jack Frost”), Shasta daisy (Lucanthemum superbum "Whoops-a-Daisy”) and rooted cuttings of phlox (Phlox paniculata “David”), liatris (Liatris spicata "Kobold Original”) and coreopsis (Coreopsis verticillata "Moonbeam") were transplanted in pots $(1.14 \mathrm{~L})$ containing either the bark-ADDF-perlite or bark-peatperlite. Plants were fertilized with a top dressing of 18N-2.6P-9.9K resin coated slow release fertilizer (Osmocote, Everris, Dublin, $\mathrm{OH}$ ) at a rate of $6 \mathrm{~g}$ per pot. Plants were grown under natural light (February-April at lat. $41.81^{\circ} \mathrm{N}$ ) in a glass greenhouse at $25^{\circ} \mathrm{C}$ day $/ 21^{\circ} \mathrm{C}$ night temperatures and overhead irrigated by hand as needed.

Growth and quality of each was evaluated based on a variety of quantitative parameters appropriate to each species' growth habits and a subjective visual evaluation once plants had reached full commercial maturity (6 weeks for brunnera, 10 weeks for coreopsis, 7 weeks for Shasta daisy, 5 weeks for liatris and 8 weeks for phlox). For brunnera, the number of flower spikes, maximum flower spike length, and canopy volume were measured. Canopy volume was derived using the formula for a semi-ellipsoid $\left(4 / 3 \pi\left(\mathrm{w}_{-} 1 / 2\right)\left(\mathrm{w} \_2 / 2\right)(\mathrm{H} / 2) / 2\right)$ where w1 and w2 are the maximum and minimum diameters and $\mathrm{H}$ is the height from the top of the pot rim. For coreopsis, 
shoot dry weight was measured. For Shasta daisy, dry weight and number of flowers were measured. For liatris and phlox, dry weight, number of stems and maximum height were measured.

Leachate (approximately 50 - $200 \mathrm{ml}$ per irrigation) was collected at each irrigation by placing pots above saucers and allowing them to drain freely. Leachate was filtered and colorimetric methods were used to measure phosphate-P [18], ammoniacal-N [19], and nitrate- $\mathrm{N}$ [20]. The volume of leachate collected from each irrigation event was measured gravimetrically to calculate cumulative quantity of phosphate leached using the concentration measured and volume collected.

Each crop trial was a completely random design. A total of 18 brunnera, 24 coreopsis, 24 leucanthemum, 24 liatris and 24 phlox were divided equally between bark-ADDF-perlite and bark-peat perlite treatments. Statistical Analysis System mixed procedure (SAS Institute Inc., Cary, NC) was used to analyze all data. Tukey's Honestly Significant Difference (HSD) test was used to find differences in treatment means at $\mathrm{P} \leq 0.05$.

\section{Results and Discussion}

There were no significant differences in initial physical properties or $\mathrm{pH}$ (5.53 for bark-peat-perlite and 5.66 for bark-ADDF-perlite) between the mixes, however, the bark-ADDF-perlite mix had a higher EC $\left(1.23 \mathrm{mS} \cdot \mathrm{cm}^{-1} \mathrm{vs}\right.$. $\left.0.16 \mathrm{mS} \cdot \mathrm{cm}^{-1}\right)$.

Of all plant growth parameters measured, the only significant differences between plants grown in bark-peatperlite and bark-ADDF-perlite were greater mean dry weights in Shasta daisy grown in the bark-ADDF-perlite mix (Table 1). Some visible differences in plant growth and development were observed between the two treatments in some species (Figure 1). Brunnera grown in both mixes produced a similar mean number of flower spikes of a similar mean length and had a similar mean canopy volume (Table 1). Brunnera grown in bark-ADDF-perlite had slightly chlorotic leaf margins (Figure 1(a)). There was no difference in mean shoot dry weight between coreopsis grown in either mix (Table 1) although coreopsis grown in bark-ADDF-perlite was slightly chlorotic and etiolated compared to those grown in bark-peat-perlite (Figure 1(b)). Shasta daisy grown in bark-ADDF-perlite had slightly greater mean dry shoot weights than those grown in bark-peat-perlite but both mixes produced similar mean numbers of flowers (Table 1) and of similar appearance (Figure 1(c)). For liatris, there were no significant differences in the mean dry shoot weight mean number of flower stems and mean maximum height between plants grown in either mix (Table 1). There were no significant differences in mean dry shoot weight mean number of flower stems and mean maximum height between phlox grown in either mix (Table 1).

A greater amount of phosphate-P (Figure 2) ammoniacal-N (Figure 3) and nitrate-N (Figure 4) was leached from pots containing the bark-ADDF-perlite mix and continued to be released through the growing season of all crops tested with the exception of ammoniacal-N leached from liatris pots, which was similar for both media.

ADDF can be used as a complete replacement for peat in nursery mix for herbaceous perennials; however, $\mathrm{pH}$, fertilizer, and irrigation management must be considered carefully when using ADDF, or any other alternative media component. In these trials, management decisions were based on established cultural recommendations for peat-based control mixes. Better results may be produced with individualized management decisions based on differences in mixes.

Results from this trial show that ADDF is a significant source of labile P and N. Leachate from bark-ADDFperlite had higher concentrations of phosphate and both $\mathrm{N}$ forms than bark-peat-perlite mix throughout the trial. The continued release of $\mathrm{P}$ may be from the dissolution of calcium phosphate minerals that are often found in

Table 1. Mean growth parameter measures for herbacious nursery crops grown in grown in bark-peat-perlite and barkADDF-perlite mixes. Significant differences $\left(^{*}\right)$ at $\mathrm{P} \leq 0.05$.

\begin{tabular}{|c|c|c|c|c|c|c|c|c|c|c|c|c|}
\hline & Brunnera & & & Coreopsis & $\begin{array}{c}\text { Shasta } \\
\text { daisy }\end{array}$ & & Liatris & & & Phlox & & \\
\hline & $\begin{array}{l}\text { Flower } \\
\text { spikes }\end{array}$ & $\begin{array}{l}\text { Max. flower } \\
\text { spike length }\end{array}$ & Volume & $\begin{array}{c}\text { Dry } \\
\text { weight }\end{array}$ & $\begin{array}{c}\text { Dry } \\
\text { weight }\end{array}$ & Flowers & $\begin{array}{c}\text { Dry } \\
\text { weight }\end{array}$ & $\begin{array}{c}\text { Flower } \\
\text { stems }\end{array}$ & Height & $\begin{array}{c}\text { Dry } \\
\text { weight }\end{array}$ & Stems & Height \\
\hline & $\#$ & mm & ml & g & g* & $\#$ & g & $\#$ & $\mathbf{m m}$ & g & $\#$ & mm \\
\hline Bark-ADDF-perlite & 2.4 & 172 & 1017 & 8.8 & 4.3 & 1.8 & 20.8 & 5.1 & 280 & 7.7 & 2.7 & 292 \\
\hline Bark-Peat-perlite & 1.8 & 171 & 791 & 9.2 & 2.7 & 1.3 & 18.6 & 6.4 & 295 & 6.9 & 3.3 & 290 \\
\hline
\end{tabular}




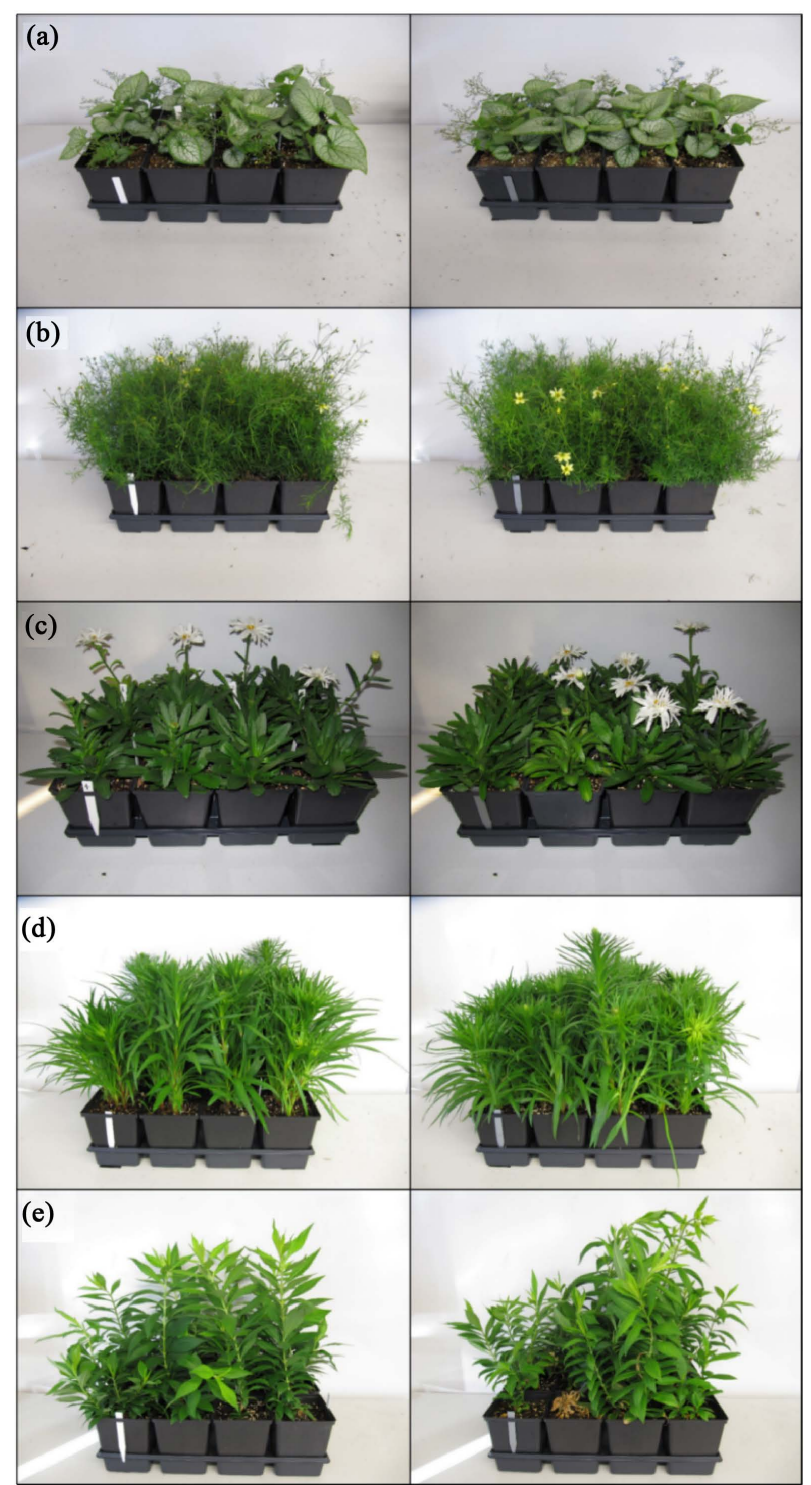

Figure 1. Brunnera (a); coreopsis (b); Shasta daisy (c); liatris (d) and phlox (e) grown in bark-peat-perlite (left) or bark-ADDF-perlite (right) nursery mixes.

dairy manure and dissolve at $\mathrm{pH}$ below 7 [21]. The continued release of $\mathrm{N}$ throughout the trial suggests the mineralization of organic $\mathrm{N}$ into plant available forms. Measures should be taken to limit nutrient leaching from ADDF-containing mixes, such as using irrigation systems with little or no leaching or adjusting fertilization regimes.

Peat usually constitutes a smaller fraction of nursery mixes than greenhouse mixes. This may have contributed to more consistently positive results with nursery crops than were reported from trials using bedding plants [8] [16]. The robust nature of herbaceous perennials may have also contributed to their growth in ADDFcontaining media. Trials with woody nursery crops in ADDF-containing media have yielded equally promising results [8].

Some of the variability in growth response of plants grown in ADDF-containing mixes may have been due to heterogeneity of the ADDF itself. The ADDF used in this project was processed to be used in the production of biodegradable pots rather than for use in potting media. Dairy farmers who wish to market ADDF as a potting media component should process their ADDF with that specific goal in mind to ensure a product uniform and consistent enough to meet the demands of growers. Liao et al. [22] have developed a leaching process specifi- 

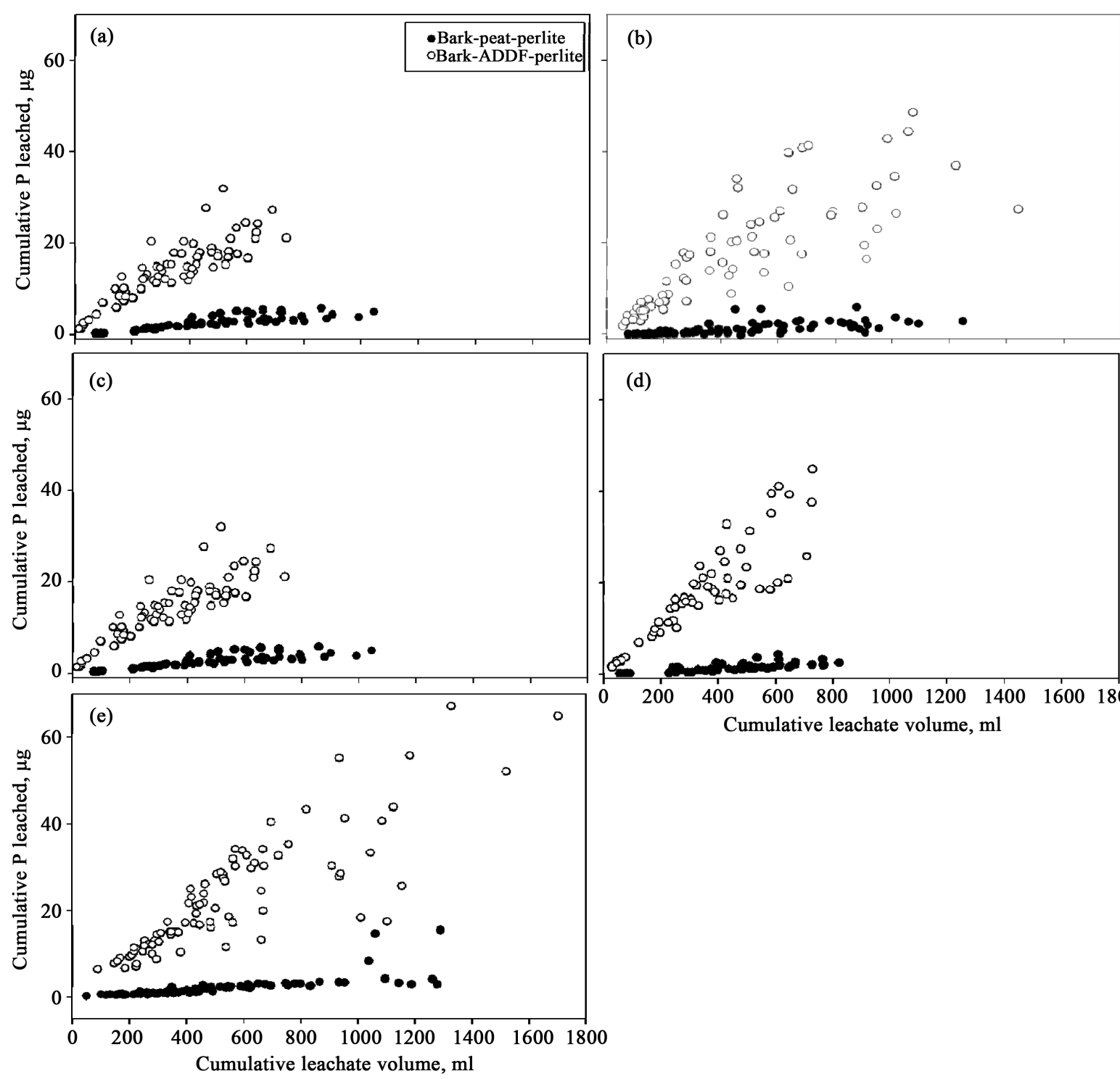

(d)

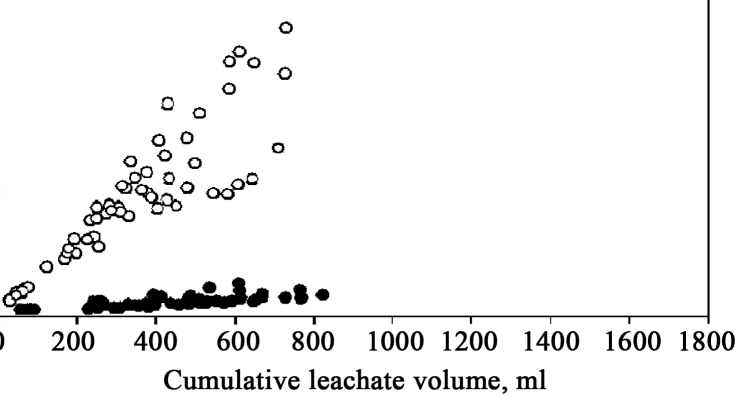

Figure 2. Cumulative phosphorus leached from brunnera (a); coreopsis (b); Shasta daisy (c); liatris (d) and phlox (e) pots containing two nursery mixes.

cally designed to process raw dairy manure into a media component; however, manure processed in this fashion has only been tested on short-term crops and many not be as resistant to degradation leading to compaction over time. MacConnell [23] has patented a process to adjust the $\mathrm{pH}$ of ADDF to an acceptable range for plant growth but processes to make physical properties of ADDF more uniform overall have not yet been reported.

There may also be variability in ADDF on a larger scale. Dairy feed can vary from region to region and seasonally, so the feedstock used to produce ADDF likely varies equally [24]. Special consideration must be given to changes in ADDF between dairies and seasons.

Anaerobic digestates, such as ADDF, would likely be much less expensive media components than peat and have the potential to offer growers significant cost savings [11]. Producing ADDF as a horticultural material could become a source of income for dairy farmers and provide a solution to some nutrient and waste management problems associated with raw manure. Leaching of nutrients from accumulated manure is a significant source of nonpoint source water pollution. If ADDF were used in growing media, nutrients that would otherwise be lost as pollutants could be used for plant nutrition; however, measures would need to be taken to avoid leaching losses. 

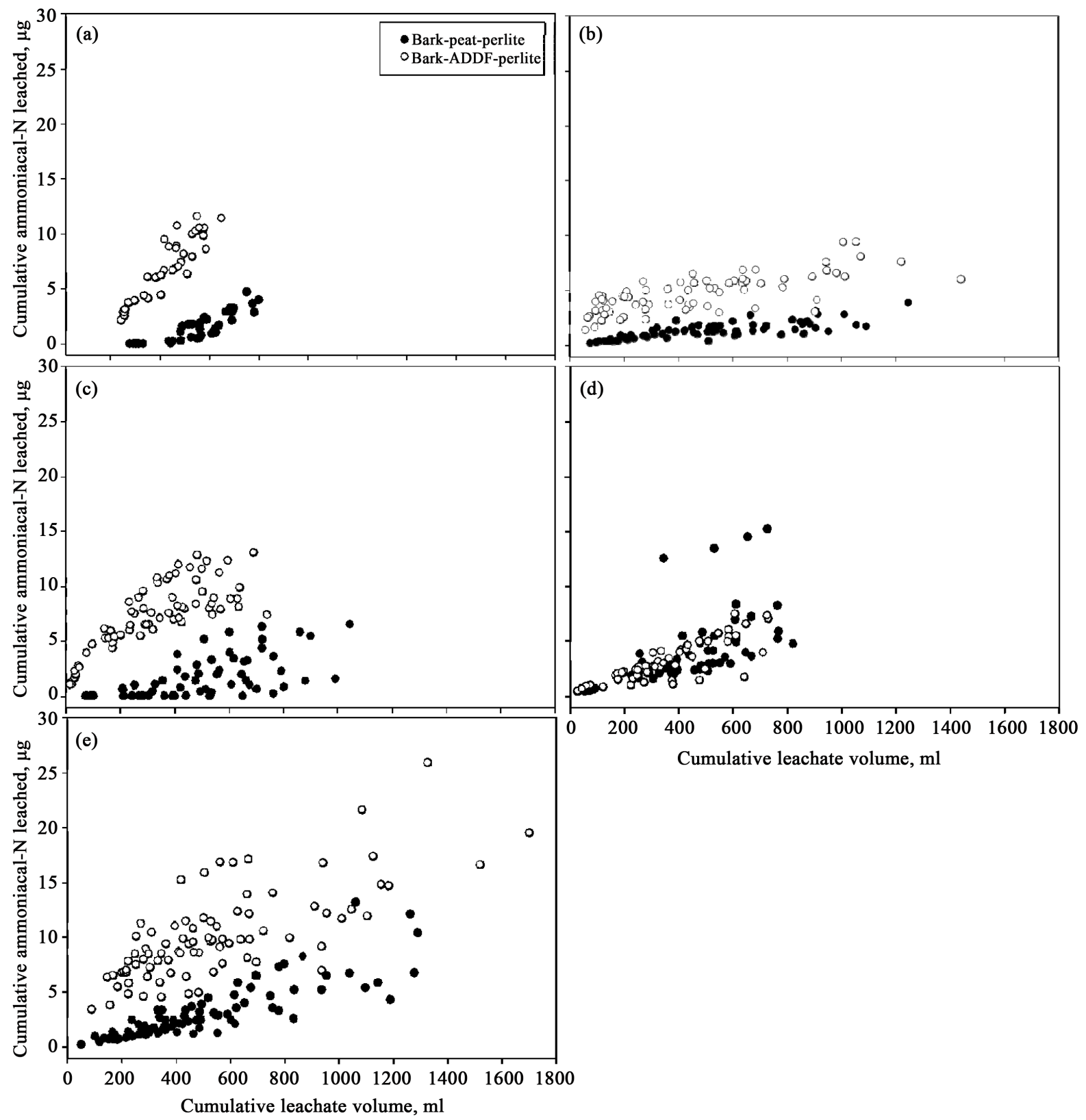

Cumulative leachate volume, $\mathrm{ml}$

Figure 3. Cumulative ammoniacal-N leached from brunnera (a); coreopsis (b); Shasta daisy (c); liatris (d) and phlox (e) pots containing two nursery mixes.

\section{Conclusion}

Best practices for containerized crops were developed for peat based media, so differences between physiochemical properties of peat and ADDF require a recalibration of best practices to optimize growth in ADDF. Although some refinement of best practices for the use of ADDF is still needed, it is an acceptable replacement for peat in media for a diversity of herbaceous perennials. Using ADDF as an alternative to peat in potting media presents opportunities for both dairy farmers and growers while promoting more sustainable practices.

\section{Acknowledgements}

We thank The Northeast Sustainable Agriculture Research and Education (SARE) graduate research grant pro- 

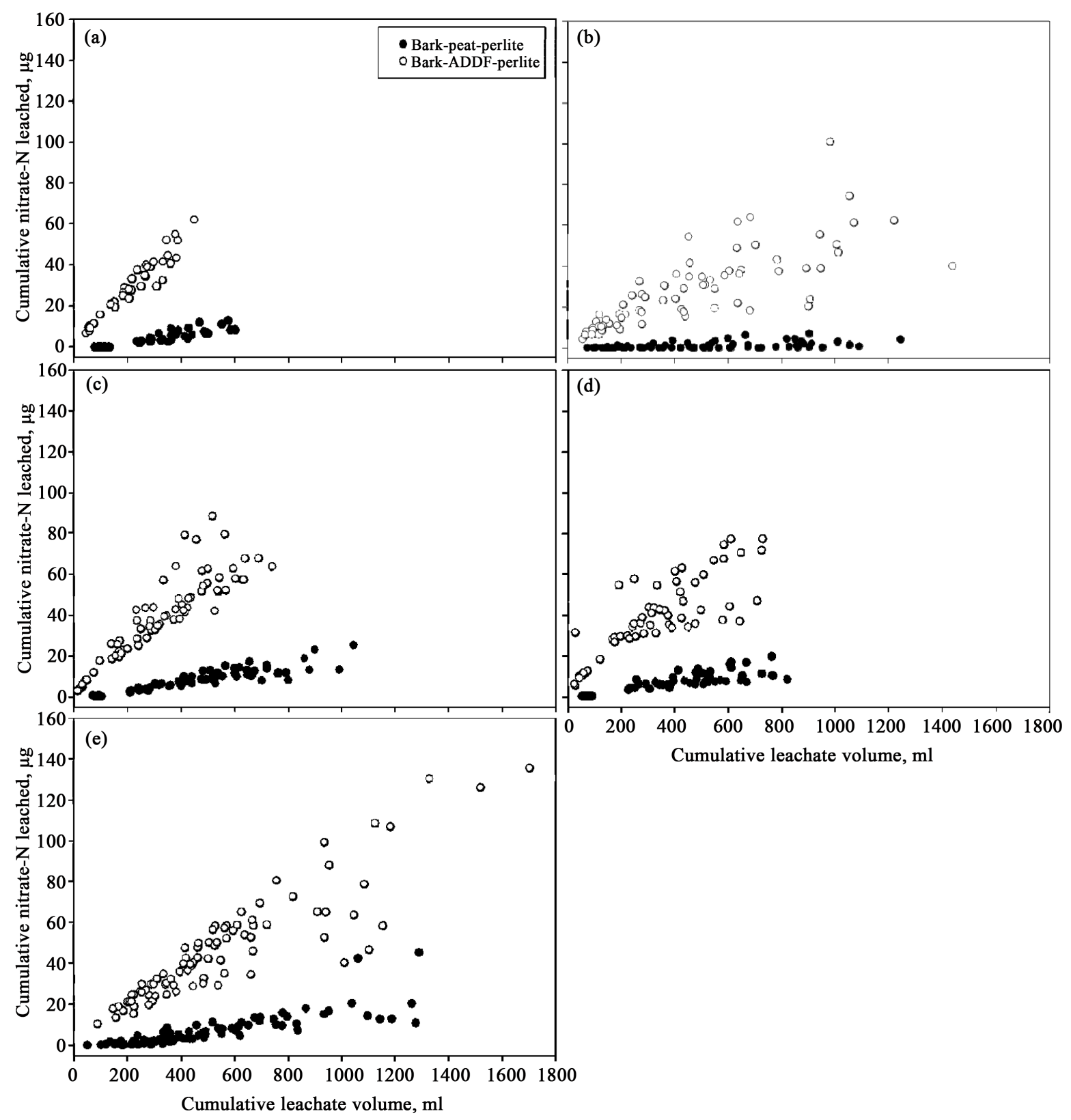

Figure 4. Cumulative nitrate-N leached from brunnera (a); coreopsis (b); Shasta daisy (c); liatris (d) and phlox (e) pots containing two nursery mixes.

gram for providing funding and Freund Farm for supplying the anaerobically digested dairy fiber used in this project.

\section{References}

[1] Handreck, K.A. and Black, N.D. (2002) Growing Media for Ornamental Plants and Turf. UNSW Press.

[2] Chalker-Scott, L. (2014) The Myth of Permanent Peatlands. Extension Urban Horticulture, Washington State University. http://puyallup.wsu.edu/wp-content/uploads/sites/403/2015/03/horticultural-peat.pdf

[3] Bullock, C.H., Collier, M.J. and Convery, F. (2012) Peatlands, Their Economic Value and Priorities for Their Future Management-The Example of Ireland. Land Use Policy, 29, 921-928.

http://dx.doi.org/10.1016/j.landusepol.2012.01.010 
[4] Raviv, M. (2005) Production of High-Quality Composts for Horticultural Purposes: A Mini-Review. HortTechnology, 15, 52-57.

[5] Moral, R., Paredes, C., Perez-Murcia, M.D., Perez-Espinosa, A. and Bustamante, M.A. (2011) Challenges of Composting for Growing Media Purposes in Spain and the Mediterranean Area. Acta Horticulturae, 1013, 25-39.

[6] Chong, C. (2005) Experiences with Wastes and Composts in Nursery Substrates. HortTechnology, 15, 739-747.

[7] Shober, A.L., Wiese, C., Denny, G.C., Stanley, C.D. and Harbaugh, B.K. (2011) Plant Performance and Nutrient Losses during Containerized Landscape Shrub Production Using Composted Dairy Manure Solids as a Peat Substitute in Substrate. HortTechnology, 21, 240-245.

[8] Lamont, J.R. (2015) Evaluating Anaerobically Digested Dairy Fiber as a Substitute for Peat in Container Production and Nutrient Availability from Organic Fertilizers and Amendments. Master's Theses, University of Connecticut, Storrs.

[9] Klavon, K.H., Lansing, S.A., Mulbry, W., Moss, A.R. and Felton, G. (2013) Economic Analysis of Small-Scale Agricultural Digesters in the United States. Biomass and Bioenergy, 54, 36-45. http://dx.doi.org/10.1016/j.biombioe.2013.03.009

[10] Miller, J. and Moyle, J. (2014) Manure as a Natural Resource: Alternative Management Opportunities. University of Maryland Extension Bulletin EB-420.

[11] Restrepo, A.P., García J.G., Moral R., Vidal F., Pérez-Murcia M.D., Bustamante, M.Á. and Paredes, C. (2013) A Comparative Cost Analysis for Using Compost Derived from Anaerobic Digestion as a Peat Substitute in a Commercial Plant Nursery. Ciencia e Investigación Agraria, 40, 253-264. http://dx.doi.org/10.4067/S0718-16202013000200002

[12] Roberston, R.A. (1993) Peat, Horticulture and Environment. Biodiversity Conservation, 2, 541-547. http://dx.doi.org/10.1007/BF00056747

[13] Lopez, R.G., Dennis, J. and Behe B.K. (2009) Consumer Perceptions of Sustainably Produced Poinsettias. Greenhouse Grower.

[14] Vaughn, S.F., Eller, F.J., Evangelista, R.L., Moser, B.R., Lee, E., Wagner, R.E. and Peterson, S.C. (2014) Evaluation of Biochar-Anaerobic Potato Digestate Mixtures as Renewable Components of Horticultural Potting Media. Industrial Crops and Products, 65, 467-471. http://dx.doi.org/10.1016/j.indcrop.2014.10.040

[15] Hernández-Apaolaza, L., Gascó, A.M., Gascó, J.M. and Guerrero, F. (2005) Reuse of Waste Materials as Growing Media for Ornamental Plants. Bioresource Technology, 96, 125-131. http://dx.doi.org/10.1016/j.biortech.2004.02.028

[16] MacConnell, C.B. and Collins, H.P. (2007) Utilization of Re-Processed Anaerobically Digested Fiber from Dairy Manure as a Container Media Substrate. Acta Horticulturae, 819, 297-286.

[17] Warnke, D. (2011) Recommended Test Procedures for Greenhouse Growth Media. In: Northeast Coordinating Committee for Soil Testing, Ed., Recommended Soil Testing Procedures for the Northeastern United States, 3rd Edition, Northeastern Regional Publication No. 493, 103-110.

[18] Murphy, J. and Riley, J.P. (1962) A Modified Single Solution Method for the Determination of Phosphate in Natural Waters. Analytica Chimica Acta, 27, 31-36. http://dx.doi.org/10.1016/S0003-2670(00)88444-5

[19] Chaney, A.L. and Marlbach, E.P. (1962) Modified Reagents for Determination of Urea and Ammonium. Clinical Chemistry, 8, 130-132.

[20] Cataldo, D.A., Haroon, M., Schrader, L.E. and Youngs, V.L. (1975) Rapid Colorimetric Determination of Nitrate in Plant Tissue by Nitration of Salicylic Acid. Communications in Soil Science \& Plant Analysis, 6, 71-80. http://dx.doi.org/10.1080/00103627509366547

[21] Shober, A.L., Wiese, C., Denny, G.C., Stanley, C.D., Harbaugh, B.K. and Chen, J. (2010) Plant Performance and Nutrient Losses during Containerized Bedding Plant Production Using Composted Dairy Manure Solids as a Peat Substitute in Substrate. HortScience, 45, 1516-1521.

[22] Liao, W., Frear, C., Oakley, K. and Chen, S. (2010) Leaching-Bed Reactor for Producing Stabilized Plant Growing Media from Dairy Manure. Biosystems Engineering, 106, 278-285. http://dx.doi.org/10.1016/j.biosystemseng.2010.03.017

[23] MacConnell, C.B. (2006) Anaerobically Digested Dairy Fiber for Use as Media Substrate. In: U.S.P.a.T. Office, Ed., Washington State University Research Foundation, Pullman.

[24] Griffin, T.S. and Honeycutt, C.W. (2000) Using Growing Degree Days to Predict Nitrogen Availability from Livestock Manure. Soil Science Society of America Journal, 64, 1876-1882. http://dx.doi.org/10.2136/sssaj2000.6451876x 